\title{
A tropical speleothem record of glacial inception, the South American Summer Monsoon from 125 to $115 \mathrm{ka}$
}

\author{
S. J. Burns ${ }^{1}$, L. C. Kanner ${ }^{1, *}$, H. Cheng ${ }^{2,3}$, and R. Lawrence Edwards ${ }^{3}$ \\ ${ }^{1}$ Department of Geosciences, University of Massachusetts, Amherst, Massachusetts 01002, USA \\ ${ }^{2}$ Institute of Global Environmental Change, Xi' an Jiaotong University, Xi' an 710049, China \\ ${ }^{3}$ Department of Geology and Geophysics, University of Minnesota, Minneapolis, MN 55455, USA \\ * present address: 2nd Nature LLC, 500 Seabright Ave, Santa Cruz, CA 95062, USA
}

Correspondence to: S. J. Burns (sburns@geo.umass.edu)

Received: 19 September 2014 - Published in Clim. Past Discuss.: 21 November 2014

Revised: 13 May 2015 - Accepted: 26 May 2015 - Published: 23 June 2015

\begin{abstract}
Relatively few marine or terrestrial paleoclimate studies have focused on glacial inception, the transition from an interglacial to a glacial climate state. As a result, neither the timing and structure of glacial inception nor the spatial pattern of glacial inception in different parts of the world is well known. Here we present results of a study of a speleothem from the Peruvian Andes that records changes in the intensity of South American Summer Monsoon (SASM) rainfall over the period from 125 to $115 \mathrm{ka}$. The results show that late in the last interglacial period, at $123 \mathrm{ka}$, SASM rainfall decreased, perhaps in response to a decrease in temperature and ice cover in the high northern latitudes and associated changes in atmospheric circulation. Then at $120.8 \mathrm{ka}$, a rapid increase in SASM rainfall marks the end of the last interglacial. After a more gradual increase between 120 and $117 \mathrm{ka}$, a second abrupt increase occurs at $117 \mathrm{ka}$. This pattern of change is mirrored to a remarkable degree by changes in the East Asian Monsoon. It is interpreted to reflect both a long-term gradual response of the monsoons to orbitally driven insolation changes and to rapid changes in Northern Hemisphere ice volume and temperature. Both monsoon systems are close to their full glacial conditions by $117 \mathrm{ka}$, before any significant decrease in atmospheric $\mathrm{CO}_{2}$.
\end{abstract}

\section{Introduction}

Studies of Earth's transitions from glacial to interglacial states over the past several hundred thousand years have focused on glacial terminations. In particular, the last glacial termination, covering the period from approximately 20 to $10 \mathrm{ka}$ has been dissected in great detail to better understand how and why glacial conditions yield to a full interglacial (see, e.g., Cheng et al., 2009a; Denton et al., 2010; Shakun et al., 2012; and references therein). But relatively few paleoclimate studies have focused on the details of the other transition between climate states - glacial inception. The relative age of the most recent glacial inception, about $120 \mathrm{ka}$, is likely a factor since far fewer high-resolution archives of climate, either marine or terrestrial, extend so far back in time.

As a result, inferred rates of glacial inception are primarily based on tuning to orbitally driven insolation changes or marine records, and are not firmly established by absolutely dated chronologies. Similarly, the timing and pattern of glacial inception in different parts of the world are not well known. Speleothems have often proven useful in adding absolute age chronologies to paleoclimate records, for example, the age and duration of Dansgaard-Oeschger (D-O) events (Wang et al., 2001; Kanner et al., 2012). They can also yield decadal-to-sub-decadal resolution paleoclimate information for many regions. Thus, well-dated, high-resolution speleothem records that cover the period of glacial inception have the potential to eliminate uncertainty in the timing and rates of climate change during glacial inception and the relationship between low- and high-latitude records. In doing so, they may also help establish the forcing necessary for the transition from one state to another. Here we present a welldated, high-resolution speleothem record of changes in the South American Summer Monsoon from 125 to $115 \mathrm{ka}$, a pe- 


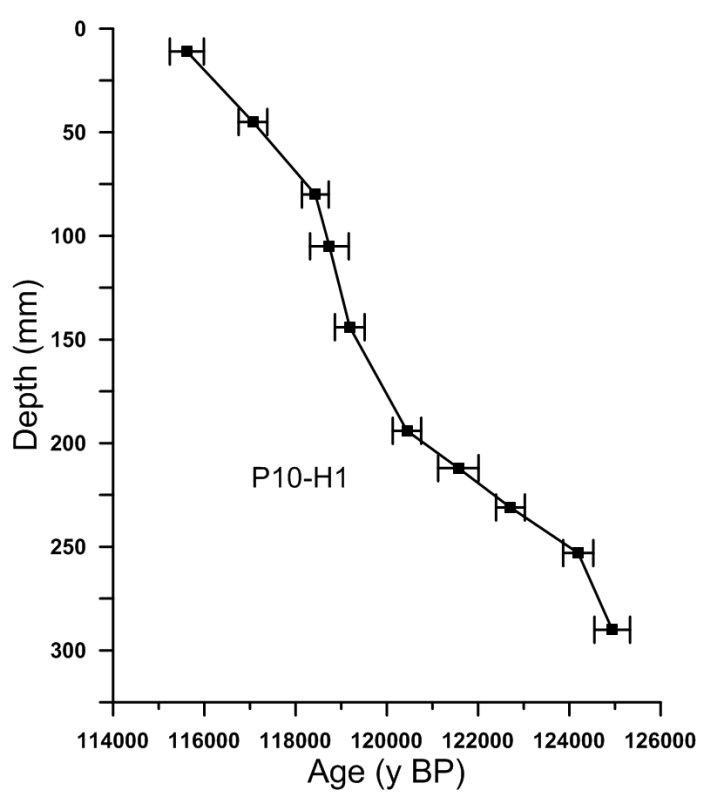

Figure 1. Age versus depth for stalagmite P10-H1. Error bars are $2 \sigma$.

riod covering the transition from the penultimate interglacial to the beginning of the last glacial period.

\section{Material and methods}

Sample P10-H1 is from Huagapo Cave $\left(11.27^{\circ} \mathrm{S}, 75.79^{\circ} \mathrm{W}\right)$ $\sim 3850 \mathrm{~m}$ above sea level (m a.s.l.) in the central Peruvian Andes. The sample is a calcite stalagmite $31.8 \mathrm{~cm}$ tall from an upper gallery of the cave approximately $700 \mathrm{~m}$ from the main entrance. The sample was cut into halves along the growth axis and polished. For radiometric dating, 10 subsamples were taken about every $30 \mathrm{~mm}$ parallel to growth layers. For stable oxygen and carbon isotope analysis, 318 subsamples were taken every millimeter along the growth axis.

The radiometric dates were measured using a multicollector, inductively coupled plasma mass spectrometer (MC-ICPMS) on a Thermo-Finnigan Neptune at the Minnesota Isotope Laboratory with procedures similar to those described in Cheng et al. (2009b). The stable isotopic analyses were performed at the University of Massachusetts using an on-line carbonate preparation system linked to a Finnigan Delta Plus XL ratio mass spectrometer. Results are reported as the per mil difference between sample and the Vienna Pee Dee Belemnite (VPDB) standard in $\delta$ notation where $\delta^{18} \mathrm{O}=\left(R_{\text {sample }} / R_{\text {standard }}-1\right) \times 1000$, and $R$ is the ratio of the minor isotope to the major isotope. Reproducibility of the standard materials is better than $0.1 \%$. Values are reported relative to the VPDB standard.

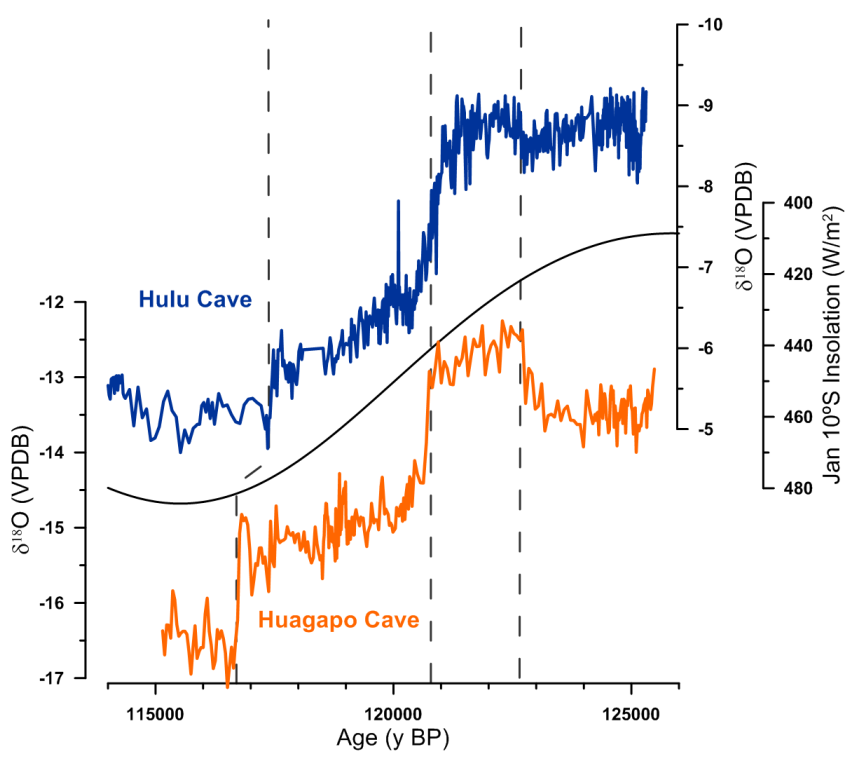

Figure 2. $\delta^{18} \mathrm{O}$ values for $\mathrm{P} 10-\mathrm{H} 1$ from Huagapo Cave in Peru plotted together with $\delta^{18} \mathrm{O}$ values for stalagmites from Hulu Cave in China (Kelly et al., 2006) and the insolation curve for $10^{\circ} \mathrm{S}$ in January (Berger, 1978).

\section{Results}

Results of U / Th isotopic analyses (Table 1) show that stalagmite P10-H1 grew from about 125.5 to $115.2 \mathrm{ka}$. All age determinations are in stratigraphic order and have errors on the order of $0.3 \%$. An age model for the oxygen stable isotope times series was constructed using linear interpolation between each age determination and is shown in Fig. 1.

The oxygen isotope time series is shown in Fig. 2, plotted together with data over the same interval from Hulu Cave in central China (Kelly et al., 2006). The $\delta^{18} \mathrm{O}$ values for P10$\mathrm{H} 1$ range from -12.3 to $-17.1 \%$. From 125 to $123 \mathrm{ka}$ the values are centered on $-13.5 \%$ and then increase to between -12.5 and -13 from 123 to $121 \mathrm{ka}$. At $120.8 \mathrm{ka}$, values decrease by more than $1 \%$ in about 120 years. They continue to decrease more slowly over the next 4 ky to around $-15.5 \%$, show a short-lived increase (about 75 years in duration) of around $0.75 \%$, and then, at $116.8 \mathrm{ka}$ decrease again rapidly to values between -16 and $-17 \%$ or the remainder of the record. The second rapid decrease occurs over about 150 years. We note that a cross plot of oxygen versus carbon stable isotope ratios for $\mathrm{P} 10-\mathrm{H} 1$ has a correlation coefficient $\left(r^{2}\right)$ of 0.06 .

\section{Discussion}

\subsection{Interpretation of oxygen isotope variability}

The oxygen isotope ratios of speleothem calcite primarily reflect changes in the oxygen isotope ratio of local precipitation (Fairchild et al., 2006; Lachniet, 2009), though factors 
Table 1. ${ }^{230}$ Th dating results of $\mathrm{P} 10-\mathrm{H} 1$.

\begin{tabular}{|c|c|c|c|c|c|c|c|c|c|c|c|c|c|c|c|c|c|c|}
\hline \multirow{2}{*}{$\begin{array}{l}\begin{array}{l}\text { Sample } \\
\text { depth } \\
(\mathrm{mm})\end{array} \\
11\end{array}$} & \multicolumn{2}{|c|}{$\begin{array}{l}{ }^{238} \mathrm{U} \\
\text { (ppb) }\end{array}$} & \multicolumn{2}{|c|}{$\begin{array}{l}{ }^{232} \mathrm{Th} \\
\text { (ppt) }\end{array}$} & \multicolumn{2}{|c|}{$\begin{array}{l}{ }^{230} \mathrm{Th} /{ }^{232} \mathrm{Th} \\
\left(\text { atomic } \times 10^{-6} \text { ) }\right.\end{array}$} & \multicolumn{2}{|c|}{$\begin{array}{c}\delta^{234} \mathrm{U}^{\mathrm{a}} \\
\text { (measured) }\end{array}$} & \multicolumn{2}{|c|}{$\begin{array}{c}{ }^{230} \mathrm{Th} /{ }^{238} \mathrm{U} \\
\text { (activity) }\end{array}$} & \multicolumn{2}{|c|}{$\begin{array}{l}{ }^{230} \text { Th age (years) } \\
\text { (uncorrected) }\end{array}$} & \multicolumn{2}{|c|}{$\begin{array}{l}{ }^{230} \text { Th age (years) } \\
\text { (corrected) }\end{array}$} & \multicolumn{2}{|c|}{$\begin{array}{l}\delta^{234} \mathrm{U}_{\text {Initial }}{ }^{\mathrm{b}} \\
\text { (corrected) }\end{array}$} & \multicolumn{2}{|c|}{$\begin{array}{c}{ }^{230} \text { Th age }(\mathrm{yr} B P)^{\mathrm{c}} \\
(\text { corrected })\end{array}$} \\
\hline & 338.8 & 0.5 & 1529 & \pm 31 & 13890.2 & \pm 278 & 4189.4 & \pm 5.8 & 3.8023 & 0.0068 & 115696 & \pm 373 & 115677 & \pm 373 & 5806.6 & \pm 10 & 115617 & \pm 373 \\
\hline 45 & 407.4 & \pm 0.4 & 1242 & \pm 25 & 19793.7 & \pm 397 & 3958.2 & \pm 3.7 & 3.6593 & 0.0058 & 117197 & \pm 314 & 117125 & \pm 314 & 5258 & \pm 11 & 117065 & \pm 314 \\
\hline 80 & 50.6 & \pm 0.1 & 128 & \pm 3 & 25978 & \pm 522 & 4351.9 & \pm 4.2 & 3.9865 & 0.0056 & 118503 & \pm 294 & 118493 & \pm 294 & 6080 & \pm 8 & 118433 & \pm 294 \\
\hline 105 & 612.5 & \pm 0.7 & 48 & \pm 2 & 828184 & \pm 26136 & 4324 & \pm 4 & 3.9716 & 0.0060 & 118803 & \pm 305 & 118802 & \pm 424 & 6046 & \pm 7 & 118740 & \pm 424 \\
\hline 144 & 404.5 & \pm 0.5 & 1658 & \pm 33 & 15959 & \pm 320 & 4306 & \pm 5 & 3.9679 & 0.0060 & 119264 & \pm 325 & 119247 & \pm 325 & 6029 & \pm 9 & 119187 & \pm 325 \\
\hline 194 & 487.2 & \pm 0.6 & 2128 & \pm 43 & 14944 & \pm 300 & 4260.8 & \pm 4.3 & 3.9600 & 0.0057 & 120519 & \pm 311 & 120500 & \pm 311 & 5987 & \pm 8 & 120440 & \pm 311 \\
\hline 212 & 416.1 & \pm 0.5 & 1139 & \pm 23 & 24631 & \pm 495 & 4368 & \pm 4 & 4.0887 & 0.0061 & 122641 & \pm 320 & 121629 & \pm 442 & 6175 & \pm 8 & 121567 & \pm 442 \\
\hline 231 & 676.0 & \pm 0.8 & 7134 & \pm 143 & 6391 & \pm 128 & 4366.4 & \pm 4.1 & 4.0908 & 0.0059 & 122811 & \pm 314 & 122769 & \pm 316 & 6174 & \pm 8 & 122709 & \pm 316 \\
\hline 253 & 491.7 & \pm 0.6 & 7723 & \pm 155 & 4372 & \pm 88 & 4420.1 & \pm 4.5 & 4.1651 & 0.0060 & 124317 & \pm 328 & 124254 & \pm 330 & 6277 & \pm 9 & 124194 & \pm 330 \\
\hline 290 & 509 & \pm 1 & 789 & \pm 16 & 45053.9 & \pm 908 & 4487.8 & \pm 4.7 & 4.2334 & 0.0075 & 125006 & \pm 390 & 124999 & \pm 390 & 6386 & \pm 10 & 124939 & \pm 390 \\
\hline
\end{tabular}

The error is $2 \sigma .{ }^{\mathrm{a}}{ }^{8234} \mathrm{U}=\left(\left[{ }^{234} \mathrm{U} /{ }^{238} \mathrm{U}\right]_{\text {activity }}-1\right) \times 1000 .{ }^{\mathrm{b}}{ }^{2344} \mathrm{U}_{\text {initial }}$ was calculated based on ${ }^{230} \mathrm{Th}$ age $(T)$, i.e., $\delta^{234} \mathrm{U}_{\text {initial }}=\delta^{234} \mathrm{U}_{\text {measured }} \times e^{\lambda 234 \times T}$. Corrected ${ }^{230} \mathrm{Th}$ ages assume the initial ${ }^{230} \mathrm{Th} /{ }^{232} \mathrm{Th}$ atomic ratio of $4.4 \pm 2.2 \times 10^{-6}$. Those are the values for a material at secular equilibrium, with the bulk Earth ${ }^{232} \mathrm{Th} /{ }^{238} \mathrm{U}$ value of 3.8 . The errors are arbitrarily assumed to be $50 \%$. ${ }^{\mathrm{c}} \mathrm{BP}$ stands for "before present" where the present is defined as the year

such as kinetic isotope effects during calcite precipitation, cave temperature, and the isotopic composition of the water vapor source may also be important. We consider these latter three factors first. Kinetic isotope effects are probably present in all speleothems (Daëron et al., 2011), yet kinetic effects can be minimized by sampling at the center of the stalagmite growth axis (Dreybrodt, 2008), which was done here. Another test of whether kinetic effects are important is the "Hendy test" (Hendy, 1971). For sample P10-H1, as noted, carbon and oxygen isotopic values along the growth axis are not correlated $\left(r^{2}=0.06\right)$, indicating that kinetic effects are not an important influence on oxygen isotope variations.

Figure 2 shows that the least negative $\delta^{18} \mathrm{O}$ values for P10$\mathrm{H} 1$ occur from about 125 to $121 \mathrm{ka}$, during the penultimate interglacial period. The most negative values, about $4.8 \%$ o lower, occur at about $115 \mathrm{ka}$, as Earth's climate made the transition to the long glacial state that followed. Accompanying the transition to a glacial climate, mean annual air temperatures likely decreased by, at most, $5^{\circ} \mathrm{C}$ at the study site, if we assume that the temperature change was less than or similar to that estimated for the transition of the Last Glacial Maximum (LGM) to Holocene (Porter, 2000). Cooler cave temperatures should lead to enriched oxygen isotope ratios in calcite, by about $1 \%$, due to an increase in the equilibrium calcite-water isotopic fractionation (Kim and O'Neil, 1997). In addition, the transition to a glacial climate resulted in increased global ice volume and an increased oxygen isotope ratio of seawater of around $0.5 \%$ (using sea level estimates for the time period and a sea level/seawater isotopic ratios of about $0.1 \% / 10 \mathrm{~m}$ ). The combined effect of these factors would be to increase the $\delta^{18} \mathrm{O}$ value of speleothem calcite by about $1.5 \%$. Thus, the observed change of $4.8 \%$ in $\mathrm{P} 10-\mathrm{H} 1$ records the minimum amplitude of changes in $\delta^{18} \mathrm{O}$ of precipitation and the effective change in $\delta^{18} \mathrm{O}$ of precipitation at the site was approximately $6.3 \%$.

The relationship between $\delta^{18} \mathrm{O}$ of precipitation at the study site and climate is as follows. During the South American Summer Monsoon (SASM), as moisture is transported from the tropical Atlantic across the continent, rainout of the heavy isotopes leads to highly depleted rainfall in the Amazon Basin. Via an "amount effect" a stronger SASM leads to more negative $\delta^{18} \mathrm{O}$ values in tropical South American rainfall $\delta^{18} \mathrm{O}$ (Vuille and Werner, 2005). Because the moisture source for the central Peruvian Andes is the Amazon Basin (Garreaud et al., 2003), a similar relationship is observed for the tropical Andes, where local precipitation $\delta^{18} \mathrm{O}$ is strongly anti-correlated to rainfall amount upstream in the Amazon Basin (Hoffmann et al., 2003; Vimeux et al., 2005) The $\delta^{18} \mathrm{O}$ of precipitation at the study site is an integrated signal of monsoon intensity along the entire moisture path from the eastern Amazon Basin to the Altiplano (Vuille and Werner, 2005; Vimeux et al., 2005). On orbital and millennial timescales, paleoclimate studies have shown that the intensity of the SASM is related to changes in the latitudinal position of the Atlantic Intertropical Convergence Zone (ITCZ). A more southerly mean position of the ITCZ leads to increased SASM intensity (Seltzer et al., 2000; Cruz et al., 2005). Thus, speleothem $\delta^{18} \mathrm{O}$ at the study site records changes in the intensity of large-scale continental and maritime atmospheric convection, and more negative speleothem $\delta^{18} \mathrm{O}$ indicates enhanced SASM activity, increased rainout, and a more southerly position of the ITCZ.

Our record shows that the SASM was relatively weak during Marine Isotope Stage (MIS) 5.5, particularly during the last 2000 years of the interglacial period. The SASM strengthened rapidly, mainly in two approximately equal steps, at $121 \mathrm{ka}$ and at $117 \mathrm{ka}$. The most negative $\delta^{18} \mathrm{O}$ values for P10-H1, around $-17.0 \%$ between 117 and $116 \mathrm{ka}$, are less than one per mil more enriched than samples from the same area during the LGM (Kanner et al., 2012). Additionally, the $\sim 5 \%$ range $\delta^{18} \mathrm{O}$ observed in $\mathrm{P} 10-\mathrm{H} 1$ is only slightly less than to the $5.5 \%$ change we observe in speleothems from this location from the LGM to the early Holocene (Kanner et al., 2013, 2012). Thus, the SASM was within $80-90 \%$ of its maximum intensity over the last glacial cycle at $116 \mathrm{ka}$, equivalent to MIS 5.4.

The intensification of the SASM during deglaciation is a response to several factors. In part, intensification is due to 
an increase in summer insolation over the Amazon Basin, driving increased convective activity moisture transport. Numerous paleoclimate studies from the EASM, Indian Summer Monsoon (ISM), and SASM regions (Cruz et al., 2005b; Fleitmann et al., 2003; Wang et al., 2008, 2005, 2001) and modeling results (Kutzbach, 1981; Kutzbach et al., 2008; Ziegler et al., 2010) indicate that the primary control on monsoon precipitation is summer insolation changes that follow the precession of Earth's orbit. The P10-H1 time series parallels January insolation at $10^{\circ} \mathrm{S}$ (Fig. 2), though the response of the SASM to insolation is clearly nonlinear. The minimum in SASM intensity and the following increase lag insolation by a few thousand years (Fig. 2). The increase also occurs mainly in two steps, not smoothly. Maximum monsoon intensity, however, is reached at close to the maximum in summer insolation at $10^{\circ} \mathrm{S}$.

The nonlinear relationship between SASM intensity and insolation indicates that additional factors account for the timing and pace of low-latitude climate change. Paleoclimate studies of speleothem growth periods (Wang et al., 2008) and oxygen isotope ratios (Kanner et al., 2012) during the last glacial period demonstrate that the SASM increased rapidly in intensity during Heinrich events and during Greenland stadials. Conversely, the SASM was relatively weak during Greenland interstadials. These changes have been interpreted as reflecting millennial-scale shifts in the mean ITCZ position (e.g., Kanner et al., 2012), a hypothesis that is supported by modeling studies of the effect of land and sea ice on the ITCZ and Hadley circulation in which cooling of the high northern latitudes results in the establishment of an interhemispheric thermal gradient (Chiang and Friedman, 2012; Donohoe et al., 2012). Because the teleconnection between high and low latitudes is through the atmosphere, the response of low-latitude atmospheric circulation is very rapid (Schneider et al., 2014). In model studies, southward movement of the ITCZ in response to imposed Northern Hemisphere $(\mathrm{NH})$ cooling occurs on the order of 1 decade (Chiang and Friedman, 2012). Analogous to changes observed for D$\mathrm{O}$ events, the rapid increases in SASM (and the East Asian Summer Monsoon; EASM) intensity at 121 and $117 \mathrm{ka}$ are likely due in large part to rapid increases in ice cover and decreases in temperature in the high northern latitudes that cause an almost immediate response in low-latitude atmospheric circulation. Thus, the observed low- and high-latitude climate changes are essentially synchronous.

\subsection{Comparison to other records}

\subsubsection{Comparison to changes in East Asian Summer Monsoon}

Our record of SASM changes over the transition from MIS 5.5 to 5.4 is mirrored to a remarkable degree by observed changes in the East Asian Monsoon (Fig. 2) as recorded in stalagmites from Dongge Cave in China (Kelly et al., 2006).
These records are shown on independent chronologies established by $\mathrm{U} / \mathrm{Th}$ dating, but with the scale for $\delta^{18} \mathrm{O}$ for Dongge inverted (Fig. 2). During the later stages of MIS 5.5 , the SASM is in a dry phase, while the EASM is in a wet phase. Isotopic values for both speleothems are fairly constant during MIS 5.5, with the exception of a small decrease of about $0.8 \%$ in $\delta^{18} \mathrm{O}$ values in Huagapo Cave that is mirrored by an increase of about $0.5 \%$ in Hulu. Both D3 and P10-H1 show a rapid change of more than $2 \%$ at $120.8 \pm 0.5 \mathrm{ka}$, with a sudden increase in SASM intensity and decrease in EASM intensity. In both records, the majority of this change occurs over less than 600 years and possibly as fast as 200 years. The absolute chronologies of these two tropical speleothems indicate the end of the last interglacial period was associated with a very large, rapid change in tropical hydrology that is synchronous in both hemispheres within the error of the chronologies. The age estimate for rapid climatic change that marks the end of the last interglacial period in Peru and Dongge Cave is also within the dating error of speleothems from China, $119 \pm 0.6 \mathrm{ka}$ (Yuan et al., 2004), the European Alps, $118 \pm 2 \mathrm{ka}$ (Meyer et al., 2008), and the eastern Mediterranean, $119 \pm 3 \mathrm{ka}$ (BarMatthews et al., 2003). Following this rapid shift is a period of slower change from 121 to $117 \mathrm{ka}$ during which both isotopic time series parallel their respective summer insolation curves (Fig. 2). A second rapid shift is observed at $117 \mathrm{ka}$ (117.5 in Dongge) with the SASM further strengthening and the EAM further weakening.

\subsubsection{Comparison to ice core records}

Figure 3 shows the $\mathrm{P} 10-\mathrm{H} 1$ data along with $\delta^{18} \mathrm{O}$ of ice from the NGRIP ice core, $\delta^{18} \mathrm{O}$ of values of atmospheric oxygen from the Vostok ice core and atmospheric methane concentrations from the EPICA Dome $\mathrm{C}$ core. To incorporate more broadly the P10-H1 data with later changes in the SASM, we spliced data from stalagmite BT2 from Botuvera Cave in southern Brazil (Cruz et al., 2005) to the end of the P10-H1 record. As is the case for $\mathrm{P} 10-\mathrm{H} 1$, the oxygen isotopic values of BT2 are primarily a function of the intensity rainfall in the SASM (Cruz et al., 2005). The growth period of BT2 overlaps growth of $\mathrm{P} 10-\mathrm{H} 1$ for about 2000 years. To put both data sets onto a common $\delta^{18} \mathrm{O}$ scale, $12.5 \%$ was subtracted from the BT2 values, yielding very similar values for the period of overlap. The BT2 age model was also adjusted for part of the record presented here. Stalagmite BT2 has only four age measurements over the oldest $35 \mathrm{ky}$ of deposition and the errors for these ages are all greater than $2 \%$ (Cruz et al., 2005). The large isotopic shift at the start of Glacial Interstadial (GIS) 24 is very well dated in speleothems from Dongge Cave in China (Kelly et al., 2006) and the European Alps (Boch et al., 2011). Therefore, the age of this shift in BT2 was adjusted to $108.0 \mathrm{ka}$ to match the better-dated records. The age adjustment ranges from a maximum of 2700 years at this shift, and decreases to 0 years for ages younger than 


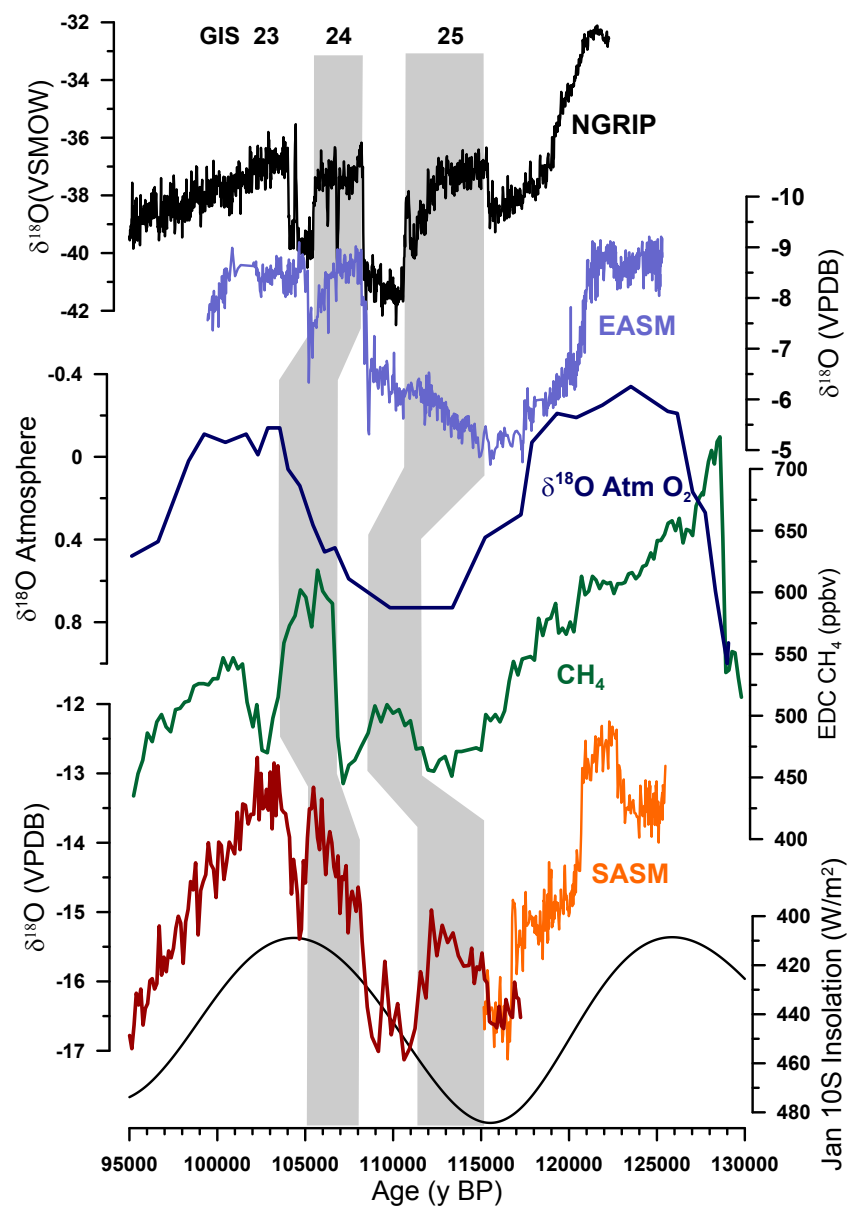

Figure 3. Oxygen isotope proxies for changes in the intensity of the South American Summer Monsoon, SASM (Cruz et al., 2005 and this paper), East Asian Monsoon, EASM (Kelly et al., 2006) and Greenland temperatures, NGRIP (Andersen et al., 2004), atmospheric methane concentrations from the EPICA Dome $\mathrm{C}$ ice core (Spahni et al., 2005), and $\delta^{18} \mathrm{O}$ values for atmospheric oxygen from the Vostok ice core (Petit et al., 1999). The records are all on independent timescales.

$102 \mathrm{ka}$ and older than $114 \mathrm{ka}$. The portion of overlap between BT2 and P10-H1 was not adjusted.

The addition of a record of SASM intensity over the period of glacial inception and the early glacial period leads to the following observations. The GISs 23, 24, and 25 all appear to have a global signal, with increases in atmospheric methane and a decrease in SASM intensity associated with each. Nearly every D-O event found in the ice cores and speleothems is coupled with a parallel change in atmospheric methane (Chappellaz et al., 2013), with Greenland interstadials associated with higher methane concentrations. This relationship is also clearly present in the earliest stages of the glacial period, with GISs 24, 25, and 26 expressed as positive $\delta^{18} \mathrm{O}$ excursions in $\mathrm{H} 09-10 \mathrm{~b}$, and increases in methane concentrations in the Vostok and EPICA Dome $\mathrm{C}$ ice cores (Fig. 3). By aligning the rapid changes in methane with rapid changes in $\delta^{18} \mathrm{O}$ in the speleothems, a chronology for changes in atmospheric gas concentrations can be established that is independent of age models for the ice cores themselves and independent of the lag in the age of trapped gases with respect to the ice itself. Based on the observed relationship between methane concentrations and millennial-scale events during MIS 3 from speleothems in the region (Kanner et al., 2012), the three methane peaks very likely are coeval with the millennial events in the tropics and with GIS 23, 24, and 25. If so, then either the GT4 chronology for Antarctic ice is a few thousand years too young, or the estimated gas age-ice age difference is too large by a similar amount.

Ice core atmospheric oxygen $\delta^{18} \mathrm{O}$ data from Vostok are also shown in Fig. 3. The $\delta^{18} \mathrm{O}_{\mathrm{atm}}$ values reach a first minimum following MIS 5.5 that is coincident with the first minimum in atmospheric methane, which the speleothem chronologies place at $116 \mathrm{ka}$, just at the transition from Glacial Stadial (GS) 25 to GIS 25 (Landais et al., 2006). We show the EDC ice core methane record because it is higher resolution than Vostok methane (note that both are on the same timescale). The large change in tropical hydrology associated with this decrease supports the hypothesis that on millennial timescales, $\delta^{18} \mathrm{O}$ atm responds strongly to changes in the monsoons (Bender et al., 1994; Hoffmann et al., 2004). It is also worth noting that in the EPICA Dome $\mathrm{C}$ ice core, $\mathrm{CO}_{2}$ concentrations remain above $260 \mathrm{ppmv}$ through the entire observed decrease in methane from 130 to $113 \mathrm{ka}$ (GT4 timescale, or $\sim 115 \mathrm{ka}$ using the stalagmite timescale). Thus, $\mathrm{CO}_{2}$ remains above $260 \mathrm{ppmv}$ during the entire period of $\mathrm{NH}$ cooling and ice growth through the first minimum in $\delta^{18} \mathrm{O}$ in stalagmites P10-H1 and D3 in Peru and China, respectively. These results are in accord with modeling studies that suggest that orbital forcing alone is sufficient to result in the growth of ice sheets in the Northern Hemisphere.

The timing of glacial inception recorded in the speleothems in both hemispheres, however, is considerably earlier, and, therefore, under conditions of higher summer insolation than is usually used in modeling studies. Modeling results indicate that tropical hydrology responds very rapidly to ice sheet expansion (Chiang and Bitz, 2005; Broccoli et al., 2006). Thus, it is reasonable to infer from the speleothem $\delta^{18} \mathrm{O}$ records that a rapid ice sheet growth began as early as $120 \mathrm{ka}$, at approximately the mid-point in the insolation curve for $\mathrm{NH}$ summer insolation.

\subsection{Implications for sea level reconstructions}

The speleothem $\delta^{18} \mathrm{O}$ data and the accuracy of the dating of the curves, also have implications for the timing of sea level changes thought to have taken place during MIS 5.5 and at the 5.5 to 5.4 transition. A number of studies have concluded than there was a rapid sea level rise near the end of MIS 5.5 (O'Leary et al., 2013; Dutton and Lambeck, 2012; Thompson et al., 2011). This rise is thought to have been the result of a rapid melting event in the high northern latitudes. If so, it 
is likely that this event would have impacted tropical hydrology, just as millennial-scale events did during glacial periods. We observe a nearly $1 \%$ increase in speleothem $\delta^{18} \mathrm{O}$ in our Huagapo Cave record at $123 \mathrm{ka}$, coincident with an $\sim 0.5$ per mil decrease in the Hulu cave record (Kelly et al., 2006). These data suggest a significant weakening in the SASM and strengthening of the EASM, as models predict for a warming of the high northern latitudes and decrease in ice cover there. We suggest that the abrupt change in tropical hydrology is associated with the late MIS 5.5 sea level change observed in other archives.

A related question is the timing of ice accumulation and sea level fall at the end of MIS 5.5. The speleothem records indicate that the end of MIS 5.5 in the tropics, marked by a rapid weakening of the EASM and strengthening of the SASM, occurred at $120.8 \pm 0.4 \mathrm{ka}$ (dating errors on P10-01 are less than 400 years, those for speleothems D3 and D4 from Hulu are $\sim 1000$ years). We infer that these changes in the monsoon are a direct response to high northern latitude cooling and increasing ice cover. In contrast, coral records of the timing of the end of MIS 5.5 indicate that sea level remained at or above present sea level until 115117 ka (O'Leary et al., 2013; Dutton and Lambeck, 2012; Thompson et al., 2011). While it is not possible to make a direct estimate of sea level fall from the speleothem records, it is unlikely that the very large changes in tropical hydrology observed could have taken place without at least several meters of sea level equivalent ice growth. Thus, we suggest that the coral ages used to estimate the timing of sea level fall are several thousand years too young, and are more impacted by diagenesis and the uncertainty in seawater $\delta^{234} \mathrm{U}$ than is commonly recognized.

\section{Conclusions}

A speleothem recovered from Huagapo cave in the Peruvian Andes records variations in the intensity of South American Summer Monsoon rainfall in the Amazon Basin from 125 to $114 \mathrm{ka}$, covering the transition from the penultimate interglacial period to the following glacial period. SASM rainfall was relatively low during the latter part of MIS 5.5, but increased rapidly at $120.8 \mathrm{ka}$ as rapidly decreasing temperatures and increasing ice cover in the high northern latitudes, marking the beginning of the last glacial period, pushed the mean position of the ITCZ to the south. By $116.8 \mathrm{ka}$ the SASM intensity was as high as at any other point during the entire last glacial period. Both the timing and pattern of changes in the SASM are mirrored to a high degree of fidelity by anti-phase changes in the East Asian Summer Monsoon. The timing of these changes in tropical hydrology thus reveals the nature of the interglacial-to-glacial transition at low latitudes. A full tropical "glacial" state was reached before any decrease in atmospheric $\mathrm{CO}_{2}$, suggesting that insolation forcing alone is sufficient to terminate interglacial periods.
Acknowledgements. This work is supported by NSF grants ATM-1003466 to S. J. Burns, 0502535 and 1103403 to R. L. Edwards and $\mathrm{H}$. Cheng. We thank Carlos Morales-Bermudez for his invaluable assistance in the field.

Edited by: D. Fleitmann

\section{References}

Andersen, K. K., Azuma, N., Barnola, J. M., Bigler, M., Biscaye, P., Caillon, N., Chappellaz, J., Clausen, H. B., Dahl-Jensen, D., and Fischer, H.: High-resolution record of Northern Hemisphere climate extending into the last interglacial period, Nature, 431, 147-151, 2004.

Bar-Matthews, M., Ayalon, A., Gilmour, M., Matthews, A., and Hawkesworth, C.: Sea-land oxygen isotopic relationships from planktonic foraminifera and speleothems in the Eastern Mediterranean region and their implication for paleorainfall during interglacial intervals, Geochim. Cosmochim. Acta, 67, 3181-3199, 2003.

Bender, M., Sowers, T., and Labeyrie, L.: The Dole Effect and its variations during the last 130000 years as measured in the Vostok Ice Core, Global Biogeochem. Cy., 8, 363-376, 1994.

Berger, A.: Long-Term Variations of Daily Insolation and Quaternary Climatic Changes, J. Atmos. Sci., 35, 2362-2367, 1978.

Boch, R., Cheng, H., Spötl, C., Edwards, R. L., Wang, X., and Häuselmann, P.: NALPS: a precisely dated European climate record 120-60 ka, Clim. Past, 7, 1247-1259, doi:10.5194/cp-71247-2011, 2011.

Broccoli, A. J., Dahl, K. A., and Stouffer, R. J.: Response of the ITCZ to Northern Hemisphere cooling, Geophys. Res. Lett., 33, L01702, doi:10.1029/2005GL024546, 2006.

Chappellaz, J., Stowasser, C., Blunier, T., Baslev-Clausen, D., Brook, E.J., Dallmayr, R., Faïn, X., Lee, J.E., Mitchell, L.E., Pascual, O., Romanini, D., Rosen, J., and Schüpbach, S.: Highresolution glacial and deglacial record of atmospheric methane by continuous-flow and laser spectrometer analysis along the NEEM ice core, Clim. Past, 9, 2579-2593, doi:10.5194/cp-92579-2013, 2013.

Cheng, H., Edwards, R.L., Broecker, W.S., Denton, G.H., Kong, X., Wang, Y., Zhang, R., and Wang, X.: Ice Age Terminations, Science, 326, 248-252, 2009a.

Cheng, H., Fleitmann, D., Edwards, R. L., Wang, X., Cruz, F. W., Auler, A. S., Mangini, A., Wang, Y., Kong, X., Burns, S. J., and Matter, A.: Timing and structure of the $8.2 \mathrm{kyr}$ B.P. event inferred from $\delta 180$ records of stalagmites from China, Oman, and Brazil, Geology, 37, 1007-1010, 2009b.

Chiang, J. C. H. and Bitz, C. M.: Influence of high latitude ice cover on the marine Intertropical Convergence Zone, Clim. Dynam., 25, 477-496, 2005.

Chiang, J. C. H. and Friedman, A. R.: Extratropical Cooling, Interhemispheric Thermal Gradients, and Tropical Climate Change, Ann. Rev. Earth Planet. Sci., 40, 383-412, 2012.

Cruz, F. W., Burns, S. J., Karmann, I., Sharp, W. D., Vuille, M., Cardoso, A. O., Ferrari, J. A., Dias, P. L. S., and Viana, O.: Insolation-driven changes in atmospheric circulation over the past 116000 years in subtropical Brazil, Nature, 434, 63-66, 2005a. 
Cruz, F. W., Burns, S. J., Karmann, I., Sharp, W. D., Vuille, M., Cardoso, A. O., Ferrari, J. A., Dias, P. L. S., and Viana, O.: Insolation-driven changes in atmospheric circulation over the past 116000 years in subtropical Brazil, Nature, 434, 63-66, 2005b.

Daëron, M., Guo, W., Eiler, J., Genty, D., Blamart, D., Boch, R., Drysdale, R., Maire, R., Wainer, K., and Zanchetta, G.: ${ }^{13} \mathrm{C}^{18} \mathrm{O}$ clumping in speleothems: Observations from natural caves and precipitation experiments, Geochim. Cosmochim. Acta, 75, 3303-3317, 2011.

Denton, G. H., Anderson, R. F., Toggweiler, J. R., Edwards, R. L., Schaefer, J. M., and Putnam, A. E.: The Last Glacial Termination, Science, 328, 1652-1656, 2010.

Donohoe, A., Marshall, J., Ferreira, D., and Mcgee, D.: The Relationship between ITCZ Location and Cross-Equatorial Atmospheric Heat Transport: From the Seasonal Cycle to the Last Glacial Maximum, J. Climate, 26, 3597-3618, 2012.

Dreybrodt, W.: Evolution of the isotopic composition of carbon and oxygen in a calcite precipitating $\mathrm{H}_{2} \mathrm{O}-\mathrm{CO}_{2}-\mathrm{CaCO}_{3}$ solution and the related isotopic composition of calcite in stalagmites, Geochim. Cosmochim. Acta, 72, 4712-4724, 2008.

Dutton, A. and Lambeck, K.: Ice Volume and Sea Level During the Last Interglacial, Science, 337, 216-219, 2012.

Fairchild, I., Smith, C., Baker, A., Fuller, L., Spotl, C., Mattey, D., and McDermott, F.: EIMP Modification and preservation of environmental signals in speleothems, Earth-Sci. Rev., 75, 105-153, 2006.

Fleitmann, D., Burns, S. J., Mudelsee, M., Neff, U., Kramers, J., Mangini, A., and Matter, A.: Holocene forcing of the Indian monsoon recorded in a stalagmite from Southern Oman, Science, 300, 1737-1739, 2003.

Garreaud, R., Vuille, M., and Clement, A. C.: The climate of the Altiplano: observed current conditions and mechanisms of past changes, Palaeogeogr. Palaeoclimatol. Palaeoecol., 194, 5-22, 2003.

Hendy, C.: The isotopic geochemistry of speleothems - I. The calculation of the effects of different modes of formation on the isotopic composition of speleothems and their applicability as palaeoclimatic indicators, Geochim. Cosmochim. Acta, 35, 801824, 1971

Hoffmann, G., Cuntz, M., Weber, C., Ciais, P., Friedlingstein, P., Heimann, M., Jouzel, J., Kaduk, J., Maier-Reimer, E., Seibt, U., and Six, K.: A model of the Earth's Dole effect, Global Biogeochem. Cy., 18, GB1008, doi:10.1029/2003GB002059, 2004.

Hoffmann, G., Ramirez, E., Taupin, J. D., Francou, B., Ribstein, P., Delmas, R., Dürr, H., Gallaire, R., Simões, J., Schotterer, U., Stievnard,M., and Werner, M. : Coherent isotope history of Andean ice cores over the last century, Geophys. Res. Lett., 30, 1179-1183, doi:10.1029/2002GL014870, 2003.

Kanner, L. C., Burns, S. J., Cheng, H., and Edwards, R. L.: HighLatitude Forcing of the South American Summer Monsoon During the Last Glacial, Science, 335, 570-573, 2012.

Kanner, L. C., Burns, S. J., Cheng, H., Edwards, R. L., and Vuille, M.: High-resolution variability of the South American summer monsoon over the last seven millennia: insights from a speleothem record from the central Peruvian Andes, Quaternary Sci. Rev., 75, 1-10, 2013.

Kelly, M. J., Edwards, R. L., Cheng, H., Yuan, D., Cai, Y., Zhang, M., Lin, Y., and An, Z.: High resolution characterization of the
Asian Monsoon between 146,000 and 99,000 years BP from Dongge Cave, China and global correlation of events surrounding Termination II, Palaeogeogr. Palaeoclimatol. Palaeoecol., 236, 20-38, 2006.

Kim, S.-T. and O'Neil, J. R.: Equilibrium and nonequilibrium oxygen isotope effects in synthetic carbonates, Geochim. Cosmochim. Acta, 61, 3461-3475, 1997.

Kutzbach, J. E.: Monsoon climate of the early Holocene: climate experiment with the earth's orbital parameters for 9000 years ago, Science, 214, 59-61, 1981.

Kutzbach, J. E., Liu, X., Liu, Z., and Chen, G.: Simulation of the evolutionary response of global summer monsoons to orbital forcing over the past 280000 years, Clim. Dyn., 30, 567-579, 2008.

Lachniet, M. S.: Climatic and environmental controls on speleothem oxygen-isotope values, Quaternary Sci. Rev., 28, 412-432, 2009.

Landais, A., Masson-Delmotte, V., Jouzel, J., Raynaud, D., Johnsen, S., Huber, C., Leuenberger, M., Schwander, J., and Minster, B.: The glacial inception as recorded in the NorthGRIP Greenland ice core: timing, structure and associated abrupt temperature changes, Clim. Dynam., 26, 273-284, 2006.

Meyer, M. C., Spötl, C., and Mangini, A.: The demise of the Last Interglacial recorded in isotopically dated speleothems from the Alps, Quaternary Sci. Rev. 27, 476-496, 2008.

O'Leary, M. J., Hearty, P. J., Thompson, W. G., Raymo, M. E., Mitrovica, J. X., and Webster, J. M.: Ice sheet collapse following a prolonged period of stable sea level during the last interglacial, Nat. Geosci., 6, 796-800, 2013.

Petit, J. R., Jouzel, J., Raynaud, D., Barkov, N. I., Barnola, J.-M., Basile, I., Bender, M., Chappellaz, J., Davis, M., Delaygue, G., Delmotte, M., Kotlyakov, V. M., Legrand, M., Lipenkov, V. Y., Lorius, C., PÉpin, L., Ritz, C., Saltzman, E., and Stievenard, M.: Climate and atmospheric history of the past 420000 years from the Vostok ice core, Antarctica, Nature, 399, 429-436, 1999.

Porter, S. C.: Snowline depression in the tropics during the Last Glaciation, Quaternary Sci. Rev., 20, 1067-1091, 2000.

Schneider, T., Bischoff, T., and Haug, G. H.: Migrations and dynamics of the intertropical convergence zone, Nature, 513, 4553, 2014.

Seltzer, G., Rodbell, D., and Burns, S.: Isotopic evidence for late Quaternary climatic change in tropical South America, Geology, 28, 35-38, 2000.

Shakun, J. D., Clark, P. U., He, F., Marcott, S. A., Mix, A. C., Liu, Z., Otto-Bliesner, B., Schmittner, A., and Bard, E.: Global warming preceded by increasing carbon dioxide concentrations during the last deglaciation, Nature, 484, 49-54, 2012.

Spahni, R., Chappellaz, J., Stocker, T. F., Loulergue, L., Hausammann, G., Kawamura, K., Flückiger, J., Schwander, J., Raynaud, D., Masson-Delmotte, V., and Jouzel, J.: Atmospheric Methane and Nitrous Oxide of the Late Pleistocene from Antarctic Ice Cores, Science, 310, 1317-1321, 2005.

Thompson, W. G., Allen Curran, H., Wilson, M. A., and White, B.: Sea-level oscillations during the last interglacial highstand recorded by Bahamas corals, Nat. Geosci., 4, 684-687, 2011.

Vimeux, F., Gallaire, R., Bony, S., Hoffmann, G., and Chiang, J. C. H.: What are the climate controls on $\delta D$ in precipitation in the Zongo Valley (Bolivia)?, Implications for the Illimani ice core interpretation, Earth Planet. Sci. Lett., 240, 205-220, 2005. 
Vuille, M., and Werner, M.: Stable isotopes in precipitation recording South American summer monsoon and ENSO variability: observations and model results, Clim. Dynam., 25, 401-413, 2005.

Wang, Y., Cheng, H., Edwards, R. L., He, Y., Kong, X., An, Z., Wu, J., Kelly, M. J., Dykoski, C. A., and Li, X.: The Holocene Asian monsoon: links to solar changes and North Atlantic climate, Science, 308, 854-857, 2005.

Wang, Y., Cheng, H., Edwards, R. L., Kong, X., Shao, X., Chen, S., Wu, J., Jiang, X., Wang, X., and An, Z.: Millennial-and orbitalscale changes in the East Asian monsoon over the past 224000 years, Nature, 451, 1090-1093, 2008.
Wang, Y. J., Cheng, H., Edwards, R. L., An, Z. S., Wu, J. Y., Shen, C. C., and Dorale, J. A.: A high-resolution absolute-dated late Pleistocene monsoon record from Hulu Cave, China, Science, 294, 2345-2348, 2001.

Yuan, D., Cheng, H., Edwards, R., Dykoski, C., Kelly, M., Zhang, M., Qing, J., Lin, Y., Wang, Y., Wu, J., Dorale, J., An, Z., and Cai, Y.: Timing, duration, and transitions of the Last Interglacial Asian Monsoon, Science, 304, 575-578, 2004.

Ziegler, M., Lourens, L. J., Tuenter, E., Hilgen, F., Reichart, G.-J., and Weber, N.: Precession phasing offset between Indian summer monsoon and Arabian Sea productivity linked to changes in Atlantic overturning circulation, Paleoceanography, 25, PA3213, doi:10.1029/2009PA001884, 2010. 